\title{
Growth and reproductive responses of true mountain mahogany to browsing
}

\author{
DEBORAH TURLEY, BRUCE A. ROUNDY, AND SCOTT C. WALKER
}

Authors are Former Graduate Assistant, Professor Department of Integrative Biology, Brigham Young University, Provo, Utah 84602; and Wildlife Biologist and Project Leader, Great Basin Research Center, Utah Division of Wildlife Resources, Ephraim, Utah 84627.

Abstract

True mountain mahogany (Cercocarpus montanus Raf.) compensates for annual growth lost to browsing under conditions of high resource availability. To develop better guidelines for its management for big game winter forage, twig demography was studied under natural herbivory and resource availability inside and outside exclosures at 1 site in the Wasatch Mountains and on 4 sites on the North Slope of the Uinta Mountains, Utah. Annual and previous years' twig lengths, as well as location and numbers of flowers and seeds were diagrammed on branches of browsed and unbrowsed shrubs in the spring or summer and fall between 1996 and 1999. Annual twig growth and flower and seed numbers of both browsed and unbrowsed shrubs were greatest in 1997 or 1998 when precipitation was highest. Utilization of annual growth varied among sites within a year and among years within a site and ranged from $<21 \%$ to $>300 \%$ when previous years' growth was browsed. Despite differences in utilization, browsed twigs compensated similarly for length lost to herbivory, so that total twig lengths remained the same over the course of the study. Although twigs on unbrowsed shrubs had less annual growth per unit branch length than those on browsed shrubs, lack of length lost to herbivory resulted in an increase in total twig length over time. Years of high resource availability are important in allowing grazing tolerant shrubs such as true mountain mahogany to compensate for years of heavy utilization. Flower and seed numbers were much higher $(P<0.05)$ on unbrowsed than browsed shrubs. Compensatory growth was enough to maintain, but not increase total twig lengths after high utilization $(>100 \%)$ even on years of high resource availability.

Key Words: twig demography, utilization, grazing optimization, compensatory growth, herbivory, shrubs, Utah, mountain brush, exclosures, Cercocarpus montanus

True mountain mahogany (Cercocarpus montanus Raf.) is one of the most important browse species in the mountain brush zone (Holechek et al. 2001), and is considered tolerant of browsing (Shepherd 1971, Davis 1990). Low growth form and basal sprouting allow big game easy accessibility to its forage (Davis 1990). On the North Slope of the Uinta Mountains, it has been heavily used in winter primarily by moose (Alces alces) and elk (Cervus elaphus), but also by deer (Odocoileus hemionus) or pronghorn antelope (Antilocapra americana) (Turley et al. 2003).

Research was funded by the Utah Division of Wildlife Resources and Brigham Young University Professional Development Funds.

Manuscript accepted 13 Feb. 03.

\section{Resumen}

Bajo condiciones de alta disponibilidad de recursos el "True mountain mahogany" (Cercocarpus montanus Raf.) compensa la perdida del crecimiento anual debido al ramoneo. Para desarrollar mejores guías para su manejo para producir forraje en invierno para la fauna silvestre mayor se estudio la demografía de las ramillas bajo herbivoría natural y disponibilidad de recursos dentro y fuera de exclusiones en un sitio en las montañas de Wasatch y en 4 sitios en la exposición norte de las montañas Uinta, Utah. La longitud anual, y la del año previo, de las ramillas, así como su localización, número de flores y semillas fueron diagramatizadas en ramas de arbustos con y sin ramoneo durante la primavera o verano y otoño entre 1996 y 1999. EI crecimiento anual de las ramillas y el número de flores y semillas de arbustos tanto ramoneados como no ramoneados fueron mayores en 1997 o 1998 cuando la precipitación fue la mayor. La utilización del crecimiento anual varió entre sitios dentro del año $y$ entre años dentro de un sitio, y fluctuó de $<21 \%$ a $>300 \%$ cuando el crecimiento del año previo fue remoneado. A pesar de las diferencias en utilización, las ramillas ramoneadas compensaron la longitud perdida por herbivoría tal que la longitud total de la ramilla permaneció igual a través del curso del estudio. Aunque las ramillas de los arbustos no ramoneados tuvieron menos crecimiento anual por unidad longitud de la ramilla que las de los arbustos ramoneados, la falta de perdida de longitud por herbivoría resultó en un incremento de la longitud total de la ramilla través del tiempo. Años con una alta disponibilidad de recursos son importantes para permitir a los arbustos tolerantes al ramoneo, tal como el "True mountain mahogany", compensar los años de utilización fuerte. El número de flores y semillas fueron mucho mayores $(P<\mathbf{0 . 0 5})$ en los arbustos sin ramoneo que en los ramoneados. El crecimiento compensatorio fue suficiente para mantener, pero no incrementar, la longitud total de las ramillas después de una alta utilización $(>100 \%)$ aun en años de alta disponibilidad de recursos.

In that study, heavy browsing reduced canopy cover and shrub size of true mountain mahogany, but shrubs on some sites with over $300 \%$ utilization of annual growth still maintained their size.

The grazing optimization hypothesis proposes that at a certain grazing intensity, production is optimized (Briske and Heitshmidt 1991). An important basis for this hypothesis is that plants can compensate for tissue lost to herbivory, and that growth may even be stimulated by tissue removal through factors such as decreased shading of photosynthetic tissue, and activation and increased flow of photosynthates, water, and nutrients to meristematic tissue (Noy-Meir 1993). The grazing optimization hypothesis has 
probably been over applied (Briske and Heithsmidt 1991), and certainly misinterpreted by those who declare it false using the damage of heavy grazing as evidence (Patten 1993). However, compensation for tissue loss has been well established (Briske 1993). Compensatory growth varies among species and even populations (Painter et al. 1989), and with resource availability for a given species (Williamson et al. 1989, Wandera et al. 1992, Briske 1993). True mountain mahogany tolerates simulated browsing when resources are highly available because of its ability to initiate long-shoot growth from available buds (Wandera et al. 1992). However, ability of true mountain mahogany and other shrubs to compensate for herbivory should be tested under field conditions of actual herbivory and resource availability to best recommend utilization and management guidelines (Wandera et al. 1992, Briske 1993, Noy-Meir 1993, Trlica and Rittenhouse 1993). The purpose of this study was to measure twig and reproductive responses of browsed and unbrowsed true mountain mahogany under field conditions to provide guidelines for its use and management.

\section{Methods}

Twig demography was studied on unbrowsed shrubs inside exclosures and browsed shrubs outside at 1 site in the Wasatch Mountains (N 39 $45^{\prime} 111^{\circ} 48.8^{\prime}$ ) and at 4 sites on the North Slope of the Uinta Mountains, Utah (N $40^{\circ} 58^{\prime} \mathrm{W} 110^{\circ}$ 4.5-14.5'). Vegetation, soils, and other characteristics of these sites have been described by Turley et al. (2003). Precipitation and temperature data for Gardner Canyon in the Wasatch Mountains were from the Nephi, Utah weather station at 1,520 m elevation located southwest $(<8 \mathrm{~km})$ of the site (NOAA 1995-1999). Precipitation data for the North Slope of the Uinta Mountains were from the Lonetree weather station (NOAA 1995-1999). Lonetree is located about 16 $\mathrm{km}$ north of the 4 sites with an elevation of 2,280 m. At Gardner Canyon, 10 mature true mountain mahogany shrubs in the exclosure and 10 in the open area were randomly chosen for branch diagramming (Roundy and Ruyle 1989). Long shoot growth was measured on 3 branches and short shoot growth was measured on 1 branch on each shrub. Short shoots were distinguished from long shoots by their lack of internode elongation for previous years' wood. Ultimately, 30 long-shoot and 9 short-shoot branches were diagrammed in the exclosure, and 29 longshoot and 12 short-shoot branches were diagrammed in the open area. At the 4 North Slope sites, 3 branch diagrams of long shoots were drawn on each of 3 to 9 randomly chosen shrubs both inside and outside the exclosures. The number of shrubs per site included Gregory Basin inside- 9, outside- 3, Poison Mountain inside- 5, outside- 7, Telephone Hollow inside- 6 , outside- 6, Widdop Mountain inside- 5 , outside- 5 .

Branches were diagrammed to record location and length of annual growth, second-year wood, third-year wood, and location of buds, flowers, and seeds. Branches were drawn freehand to scale on 20 by 28 $\mathrm{cm}$ paper. All lengths were measured to the nearest millimeter. Each paper was photocopied, and branches were rediagrammed in the spring after winter browsing, and in the summer or fall after summer growth. Branches were diagrammed for twig growth from 1996 through 1999. At all sites, the number of seeds was recorded on diagrams in the springs of 1997, 1998, and 1999. The number of flowers per branch was recorded in 1997 through 1998 at the North Slope sites and in 1997 and 1998 at Gardner Canyon.

Number of branches diagrammed each year that produced annual growth, flowers, seeds, and that were browsed were counted to determine branch activity. Annual growth browsed as a percentage of total annual growth was calculated to give percent utilization (USDA Forest Service 1979). This results in $>100 \%$ utilization when previous years' growth is browsed. To determine branch size, total twig length of individual twigs was summed for each branch diagram. To determine increases in branch size over time, total twig length for a sample date was divided by total twig length from initial branch diagrams and measurements made in summer and fall 1996

Annual growth estimates included annual growth length per branch and annual growth length at the end of the growing season per total twig length at the beginning of the growing season. Annual twig growth per branch was the current annual growth produced by the individual branch divided by the number of current annual twigs produced by that branch. Flower and seed data were analyzed as numbers per branch, and numbers per total twig length. The number of seeds per flower and branch was also calculated.

The ratio of twig length produced in a given year to total twig length was calculated for 1995 through 1998 to determine differences in branch demography between treatments and over time. For example, ratios of 1998, 1997, and 1996 wood over total twig length and 1995 and older wood over total twig length were calculated.

Total precipitation and mean temperature at Gardner Creek were tested for correlation with mean annual twig growth per branch, mean annual twig growth of growing twigs per branch, mean annual growth length per branch, and mean seeds per branch. Annual growth was tested for correlation for the years 1996 through 1999. Seeds per branch were tested for correlation for years 1997 through 1999. Correlation analysis of North Slope sites used years 1996 to 1999 , except for seeds per branch, which used years 1997 to 1999 .

An ANOVA mixed model approach using SAS (Littell et al. 1996) was used to statistically analyze data from twig diagrams. Fixed effects included browsing compared to no browsing and site. The random effects included shrubs nested within browsing treatment at the Gardner Creek site and shrubs nested within site and browsing treatment at the North Slope sites. Individual branches were nested within shrubs, browsing treatments, and sites. Shrubs were nested within browsing treatment because they were not blocked within treatments and were a random sample of those plants within that treatment. Sites were kept as a fixed variable, in which case inferences should only be made to the communities that were sampled.

Three types of analysis were done. The first was a simple ANOVA, in which browsed and unbrowsed treatments were compared within a single year. All responses were analyzed with this simple ANOVA to compare treatments within years. Ratio of annual wood was only analyzed in this within-year ANOVA.

The second analysis was a repeated measures ANOVA with year as a class variable in which each year is considered independent of all other years. This was used in the case of the responses of annual growth length per branch, annual growth length per total twig length, annual twig growth per branch, annual twig growth of growing twigs per branch, length browsed per branch, flowers per branch, flowers per total twig length, seeds per branch, and seeds per total twig length. Because these response variables may react differently under different climatic conditions from year to year, each year was seen as a class variable and not continuous. All browsing responses for Gardner Canyon were analyzed with year as the only variable. All 
browsing responses for the North Slope sites were analyzed for site, year, and their interaction, and when site was significant, only year.

The third type of analysis was a repeated measures ANOVA with year as a continuous variable in which each year was considered dependent on the other years. This was used with the variables total twig length per branch, and total twig length of a given year divided by total twig length in 1996. All sites at the North Slope were analyzed together unless site was significant, in which case an ANOVA was done for each site individually and between treatments.

All 3 types of analysis used a backwards elimination in which nonsignificant effects were taken out of the model to achieve greater sensitivity of the tests by estimating the error terms more accurately. Because $\mathrm{P}$-values $<0.25$ may show trends, nonsignificant effects were taken out only when the P-value was $>0.25$ to be conservative. Random effects were eliminated first and then fixed effects when necessary. A square root transformation was performed on all data prior to analysis.

\section{Results}

\section{Twig Growth}

Precipitation variables were significantly $(\mathrm{P}<0.05)$ positively correlated with various growth variables for browsed shrubs. At Gardner Canyon and Telephone Hollow annual growth per total twig length was correlated with total precipitation $\left(r^{2}=0.99,0.96\right)$. At Gardner Canyon annual growth per branch was significantly correlated with June precipitation $\left(r^{2}=\right.$ 0.99). At Poison Mountain and Telephone Hollow, annual growth per branch was correlated with total precipitation $\left(\mathrm{r}^{2}=\right.$ $0.99,0.96)$. At Gregory Basin, annual growth per branch was correlated with August precipitation $\left(r^{2}=0.98\right)$, while at Widdop Mountain annual growth per branch was correlated with June through August precipitation $\left(r^{2}=0.95\right)$. Only at Widdop Mountain was there a significant positive correlation between annual growth and precipitation for unbrowsed shrubs. At that site, annual growth per branch was significantly correlated with June through August precipitation $\left(\mathrm{r}^{2}=\right.$ $0.96)$. Greater total precipitation and higher summer precipitation for the Nephi station in 1998 and for the Lonetree station in 1997 and 1998 (Figs. 1,2, and 3) were associated with greater annual growth for these years.
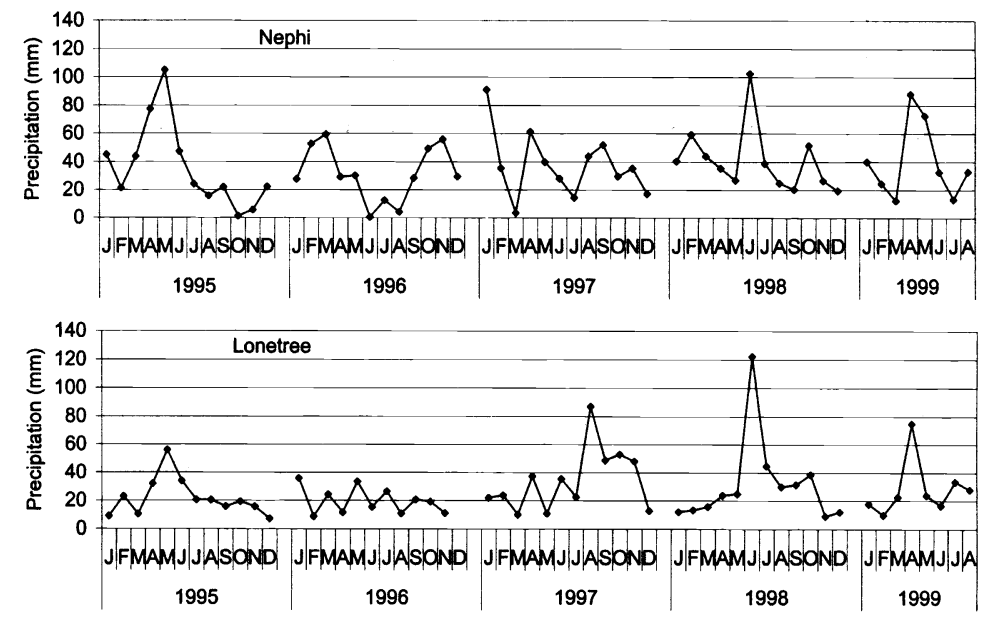

Fig. 1. Monthly precipitation at the Nephi, Utah and Lonetree, Wyo. stations.
Utilization of annual growth averaged 175,296 , and $31 \%$ for 1997,1998 , and 1999 at Gardner Creek (Turley et. al 2003). Utilization $>100 \%$ indicates browsing removed previous years' wood. Branches of long shoots at this site with active twig growth averaged $85 \%$ for browsed and $55 \%$ for unbrowsed shrubs from 1996 through 1999. In contrast, branches of short shoots with twig growth averaged only $33 \%$ for browsed and $11 \%$ for unbrowsed shrubs. Short shoots at this site grew very little and growth parameters did not vary with browsing treatment or
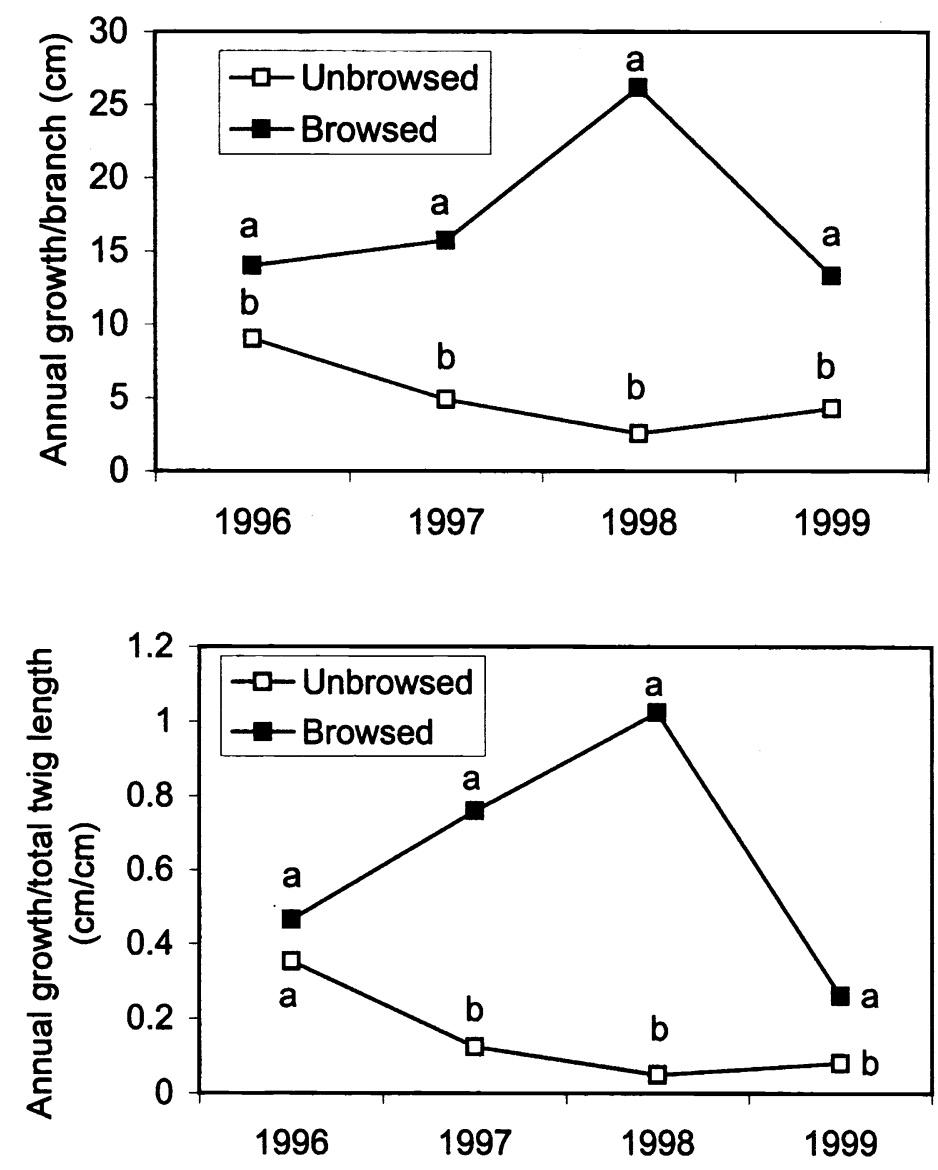

Fig. 2. Annual twig growth per branch (above) and per total twig length (below) for unbrowsed and browsed true mountain mahogany shrubs at Gardner Canyon, Utah Different letters within a year indicate a significant difference $(P<0.05)$. 
year. They were easily distinguished from long shoots by lack of internode elongation for previous years' wood. The number of branches with active long shoot growth was high (> 90\%) for browsed shrubs following years of high utilization (1997, 1998), but declined (55\%) in 1999 after low utilization in the winter of 1998 to 1999. Branches with active long shoot growth declined for unbrowsed shrubs at Gardner Creek from 1996 (90\%) to 1999 $(33 \%)$.

At the North slope, utilization of annual growth for 1997, 1998, and 1999 was 29 168 , and $21 \%$ at Gregory Basin; 46, 41, and $50 \%$ at Poison Mountain; 302, 306, and $61 \%$ at Telephone Hollow; and 149, 83 , and $62 \%$ at Widdop Mountain (Turley et al. 2003). Branches with active twig growth averaged from 1996 through 1999, for browsed and unbrowsed shrubs were 32 and $31 \%$ at Gregory Basin, 59 and $35 \%$ at Poison Mountain, 60 and 34\% at Telephone Hollow, and 75 and $65 \%$ at Widdop Mountain. At all of the North Slope sites and for both browsed and unbrowsed shrubs, the percentage of branches with active growth increased from 1996 through 1997 (42 to 66\%), then decreased in $1998(55 \%)$, and 1999 (32\%).

The interaction of browsing treatment and year was significant $(\mathrm{P}<0.001)$ for growth parameters of long shoots at Gardner Canyon (Figs. 2 and 4). Annual growth of long shoots was greater for browsed than unbrowsed shrubs for all years. However, because of growth removed by browsing, total twig length was similar for browsed and unbrowsed shrubs (Fig. 4). Total twig length for both browsed and unbrowsed shrubs increased over time at Gardner Canyon, however, annual twig growth of unbrowsed shrubs decreased over time (Fig. 2). Annual twig growth of only growing twigs was similar to that depicted for annual growth on a per branch or per total twig length basis in Figure 4.

Growth responses at the North Slope were significant for site, browsing treatment, year, and many of the 2-way interactions of these factors $(P<0.05)$. The 3 way interaction of site, treatment, and year was not significant for any responses. Annual growth length per branch was significantly greater $(P<0.05)$ for browsed than unbrowsed shrubs at Gregory Basin for all years except 1998, and for Telephone Hollow in 1997 and 1998 (Fig. 3). Annual growth length per branch for all other North Slope sites and years did not differ for browsed and unbrowsed shrubs, but annual growth per total twig
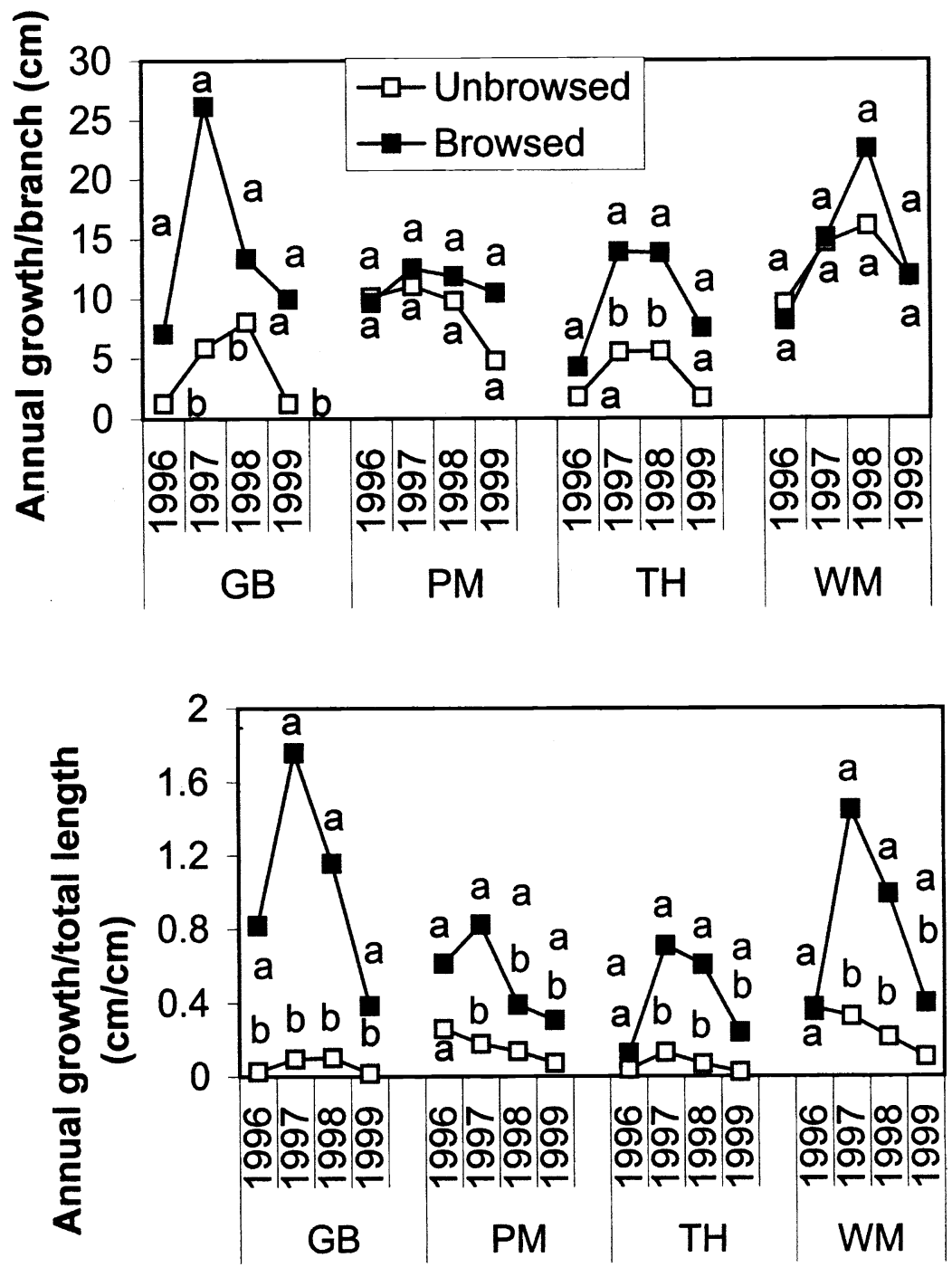

Fig. 3. Annual twig growth per branch (above) and per total twig length (below) for unbrowsed and browsed true mountain mahogany shrubs at 4 sites on the North Slope of the Uinta Mountains, Utah. GB = Gregory Basin, PM = Poison Mountain, $\mathbf{T H}=$ Telephone Hollow, WM = Widdop Mountain. Different letters within a site and year indicate a significant difference $(P<\mathbf{0 . 0 5})$.

length was greater for browsed than unbrowsed shrubs for all sites for 1997 through 1999 (Fig. 3). Annual growth of growing twigs only was not greater for browsed than unbrowsed shrubs, but more twigs had active growth on browsed than unbrowsed shrubs. Annual growth per total twig length decreased after 1997 for both browsed and unbrowsed shrubs (Fig. 3). Total twig length per branch was significantly greater for unbrowsed than browsed shrubs at most North Slope sites in most years except 1996 (Fig. 5). Total twig length per 1996 total twig length was greater for unbrowsed than browsed shrubs only at Widdop Mountain. Total twig length per branch increased over time for unbrowsed shrubs at all sites, but more so at Poison and Widdop Mountain, than at Gregory Basin and Telephone Hollow (Fig. 5). Total twig length per branch remained the same over time, or decreased slightly for browsed shrubs.

Ratios of annual wood length to total length grown in a given year measured for diagrammed branches each year provide a demographic picture of twig growth, loss, and replacement through time (Fig. 6). At Gardner Canyon, branches of long shoots of browsed shrubs had increasing ratios of current wood over time, while the opposite was true for unbrowsed shrubs (Fig. 6). Shrubs at Gregory Basin showed the same trends as those at Gardner Canyon in ratio of annual wood. At Poison Mountain and Telephone Hollow there were no signifi- 
Table 1. Numbers of seeds and flowers produced by unbrowsed and browsed true mountain mahogany shrubs at 5 sites in Utah.

\begin{tabular}{|c|c|c|c|c|c|c|c|}
\hline \multirow[t]{2}{*}{ Site } & \multirow[t]{2}{*}{ Variable } & \multicolumn{2}{|c|}{1997} & \multicolumn{2}{|c|}{1998} & \multicolumn{2}{|c|}{1999} \\
\hline & & Unbrowsed & Browsed & Unbrowsed & Browsed & Unbrowsed & Browsed \\
\hline \multicolumn{2}{|l|}{ Gardner Canyon } & --- & & & Jo.)----- & & \\
\hline \multicolumn{8}{|l|}{--- } \\
\hline \multirow[t]{4}{*}{ Long shoots } & Flowers /branch & - & - & $34.9 \mathrm{a}$ & $13.4 \mathrm{~b}$ & $1.2 \mathrm{a}$ & $1.8 \mathrm{a}$ \\
\hline & Flowers/total twig length & - & - & $1.0 \mathrm{a}$ & $0.6 \mathrm{~b}$ & $0.0 \mathrm{a}$ & $0.0 \mathrm{a}$ \\
\hline & Seeds/branch & 10.6a & $5.7 b$ & $20.7 \mathrm{a}$ & $10.6 b$ & $0.0 \mathrm{a}$ & $0.0 \mathrm{a}$ \\
\hline & Seeds/total twig length & $0.3 \mathrm{a}$ & $0.1 b$ & $0.6 \mathrm{a}$ & $0.4 \mathrm{a}$ & $0.0 \mathrm{a}$ & $0.0 \mathrm{a}$ \\
\hline \multirow[t]{4}{*}{ Short shoots } & Flowers /branch & - & - & $31.2 \mathrm{a}$ & $10.1 \mathrm{~b}$ & $1.6 \mathrm{a}$ & $0.2 \mathrm{a}$ \\
\hline & Flowers/total twig length & - & - & $0.5 \mathrm{a}$ & $0.2 \mathrm{a}$ & $0.0 \mathrm{a}$ & $0.0 \mathrm{a}$ \\
\hline & Seeds/branch & $18.0 \mathrm{a}$ & $4.9 \mathrm{~b}$ & $16.0 \mathrm{a}$ & $8.4 \mathrm{a}$ & $0.0 \mathrm{a}$ & $0.0 \mathrm{a}$ \\
\hline & Seeds/total twig length & $0.7 \mathrm{a}$ & $0.1 b$ & $0.2 \mathrm{a}$ & $0.2 \mathrm{a}$ & $0.0 \mathrm{a}$ & $0.0 \mathrm{a}$ \\
\hline \multicolumn{8}{|l|}{ North Slope Unitas } \\
\hline \multirow[t]{5}{*}{ Gregory Basin } & Flowers/branch & $11.2 \mathrm{a}$ & $2.0 \mathrm{a}$ & 43.0a & $5.2 \mathrm{a}$ & $7.0 \mathrm{a}$ & $0.3 \mathrm{~b}$ \\
\hline & Flowers/total twig length & $0.2 \mathrm{a}$ & $0.0 \mathrm{~b}$ & $0.7 \mathrm{a}$ & $0.5 \mathrm{a}$ & $0.1 \mathrm{a}$ & $0.0 \mathrm{a}$ \\
\hline & Seeds/branch & $6.6 \mathrm{a}$ & $0.9 \mathrm{~b}$ & $35.8 \mathrm{a}$ & $2.4 \mathrm{a}$ & $3.9 \mathrm{a}$ & $0.0 \mathrm{a}$ \\
\hline & Seeds/total twig length & $0.1 \mathrm{a}$ & $0.0 \mathrm{a}$ & $0.5 \mathrm{a}$ & $0.3 \mathrm{a}$ & $0.0 \mathrm{a}$ & $0.0 \mathrm{a}$ \\
\hline & Seeds/flower & $0.4 \mathrm{a}$ & $0.1 \mathrm{a}$ & $0.6 \mathrm{a}$ & $0.3 \mathrm{a}$ & $0.2 \mathrm{a}$ & $0.0 \mathrm{a}$ \\
\hline \multirow[t]{5}{*}{ Poison Mountain } & Flowers/branch & $38.9 \mathrm{a}$ & $0.6 \mathrm{~b}$ & $67.2 \mathrm{a}$ & $3.1 \mathrm{~b}$ & $41.2 \mathrm{a}$ & $0.0 \mathrm{~b}$ \\
\hline & Flowers/total twig length & $0.8 \mathrm{a}$ & $0.1 \mathrm{~b}$ & $1.1 \mathrm{a}$ & $0.3 b$ & $0.7 \mathrm{a}$ & $0.0 \mathrm{~b}$ \\
\hline & Seeds/branch & $25.3 \mathrm{a}$ & $0.3 \mathrm{~b}$ & $64.7 \mathrm{a}$ & $1.6 \mathrm{~b}$ & $28.2 a$ & $0.0 \mathrm{~b}$ \\
\hline & Seeds/total twig length & $0.5 \mathrm{a}$ & $0.0 \mathrm{~b}$ & $1.1 \mathrm{a}$ & $0.2 \mathrm{~b}$ & $0.5 \mathrm{a}$ & $0.0 \mathrm{~b}$ \\
\hline & Seeds/flower & $0.6 \mathrm{a}$ & $0.1 \mathrm{~b}$ & $1.0 \mathrm{a}$ & $0.1 \mathrm{~b}$ & $0.6 \mathrm{a}$ & $0.0 \mathrm{~b}$ \\
\hline \multirow[t]{5}{*}{ Telephone Hollow } & Flowers/branch & $13.5 \mathrm{a}$ & $0.3 \mathrm{~b}$ & $27.5 \mathrm{a}$ & $0.7 \mathrm{~b}$ & $5.9 \mathrm{a}$ & $0.0 \mathrm{~b}$ \\
\hline & Flowers/total twig length & $0.4 \mathrm{a}$ & $0.1 \mathrm{~b}$ & $0.6 \mathrm{a}$ & $0.1 \mathrm{~b}$ & $0.1 \mathrm{a}$ & $0.0 \mathrm{~b}$ \\
\hline & Seeds/branch & $8.7 \mathrm{a}$ & $0.2 \mathrm{~b}$ & 19.1a & $0.3 \mathrm{~b}$ & $1.7 \mathrm{a}$ & $0.0 \mathrm{a}$ \\
\hline & Seeds/total twig length & $0.2 \mathrm{a}$ & $0.0 \mathrm{~b}$ & $0.4 \mathrm{a}$ & $0.0 \mathrm{~b}$ & $0.0 \mathrm{a}$ & $0.0 \mathrm{a}$ \\
\hline & Seeds/flower & $0.5 \mathrm{a}$ & $0.1 \mathrm{~b}$ & $0.6 \mathrm{a}$ & $0.1 \mathrm{~b}$ & $0.2 \mathrm{a}$ & $0.0 \mathrm{~b}$ \\
\hline \multirow[t]{5}{*}{ Widdop Mountain } & Flowers/branch & $2.5 \mathrm{a}$ & $0.3 \mathrm{~b}$ & $23.9 \mathrm{a}$ & $5.3 b$ & $1.0 \mathrm{a}$ & $0.0 \mathrm{a}$ \\
\hline & Flowers/total twig length & $0.1 \mathrm{a}$ & $0.0 \mathrm{a}$ & $0.3 \mathrm{a}$ & $0.2 \mathrm{a}$ & $0.0 \mathrm{a}$ & $0.0 \mathrm{a}$ \\
\hline & Seeds/branch & $0.9 \mathrm{a}$ & $0.3 \mathrm{a}$ & $12.7 \mathrm{a}$ & $2.7 \mathrm{~b}$ & $0.2 \mathrm{a}$ & $0.0 \mathrm{a}$ \\
\hline & Seeds/total twig length & $0.0 \mathrm{a}$ & $0.0 \mathrm{a}$ & $0.2 \mathrm{a}$ & $0.1 \mathrm{~b}$ & $0.0 \mathrm{a}$ & $0.0 \mathrm{a}$ \\
\hline & Seeds/flower & $0.1 \mathrm{a}$ & $0.0 \mathrm{a}$ & $0.4 \mathrm{a}$ & $0.1 \mathrm{~b}$ & $0.0 \mathrm{a}$ & $0.0 \mathrm{a}$ \\
\hline
\end{tabular}

$\overline{\mathrm{ab}}$ means for unbrowsed and browsed shrubs within a year with a different letter are significantly $(\mathrm{P}<0.05)$ different by ANOVA.

cant differences between unbrowsed and browsed shrubs over time except in 1999, when 1998 and 1999 growth made up a greater proportion of total length for browsed than unbrowsed shrubs. Branches of browsed shrubs at Telephone Hollow had significantly more 1995 wood than branches of unbrowsed shrubs in 1997. Branches of unbrowsed and browsed shrubs at Widdop Mountain did not differ significantly in ratios of annual wood over time except that browsed shrubs had significantly lower ratios of 1996 wood after 1997 than unbrowsed shrubs. Ratio data show how newer growth increasingly replaced older wood and wood lost to browsing.

\section{Flower and Seed Production}

At Gardner Creek, the number of seeds per branch was significantly $(\mathrm{P}<0.05)$ negatively correlated with mean air temperature in June for both unbrowsed $\left(\mathrm{r}^{2}=\right.$
$0.99)$ and browsed $\left(r^{2}=0.99\right)$ shrubs. Although no correlations of reproductive responses with precipitation variables were significant, greater winter-spring precipitation in 1997-1998 was associated with much greater seed production that spring than in the springs of 1997 or 1999 when winter-spring precipitation was less. No simple positive or negative correlations were found between branches that produced flowers and seeds and branches that produced growth overall or within treatments or years at Gardner Canyon.

At the North Slope, the number of seeds per branch was significantly positively correlated with June precipitation for unbrowsed shrubs at all sites $\left(\mathrm{r}^{2}=\right.$ 0.94-0.99) and for browsed shrubs for all sites but Telephone Hollow $\left(\mathrm{r}^{2}=\right.$ 0.96-0.99). For all North Slope sites, seed production was highest in 1998, when June precipitation was highest, and lowest in 1999 when June precipitation was least for years that seed production was measured (Fig. 1, Table 1).

At Gardner Canyon for long shoots, the main and interaction effects of year and browsing were significant $(P<0.05)$ for number of flowers per branch, and number of seeds per branch and per total twig length. For short shoots at Gardner Creek, browsing treatment and year were significant $(P<0.05)$ for the number of seeds per branch and year was significant for the number of seeds per total twig length. Both long and short shoots produced similar amounts of flowers and seeds (Table 1). During the 2 years of highest seed production $(1997,1998)$, long shoots on unbrowsed shrubs produced almost twice as many seeds per branch as those on browsed shrubs (Table 1). Short shoots on unbrowsed shrubs produced over twice as many seeds per branch in 1997 and flowers per branch in 1998 as those on browsed shrubs. Ratios of seeds per flower for long shoots and short shoots on 

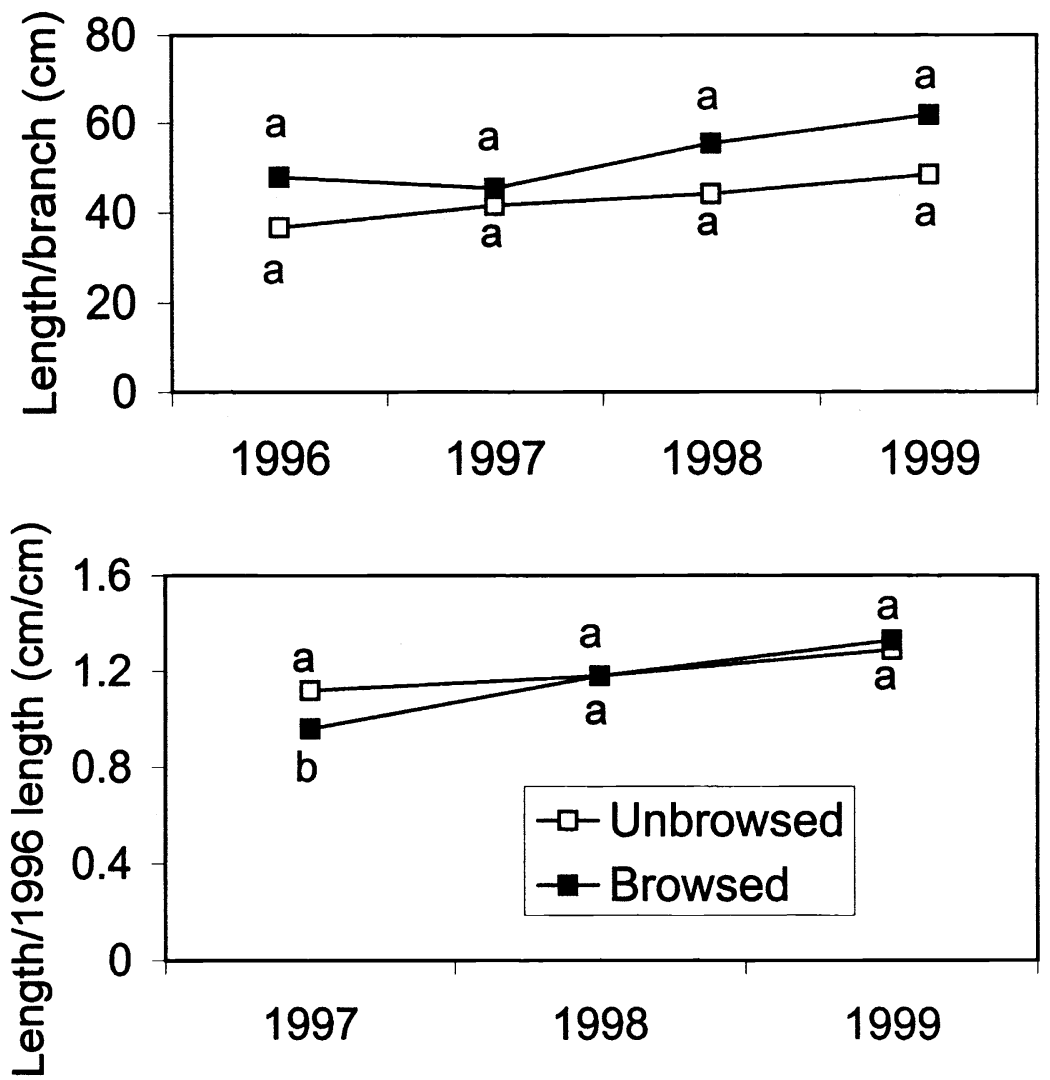

Fig. 4. Total twig length per branch (above) and per total twig length in 1996 (below) for unbrowsed and browsed true mountain mahogany shrubs at Gardner Canyon, Utah. Different letters within a year indicate a significant difference $(P<0.05)$.

unbrowsed shrubs $(0.52,0.41)$, and on browsed shrubs $(0.57,0.56)$ did not significantly $(\mathrm{P}>0.05)$ differ during the only year measured (1998), which was also the year of highest seed production.

For the North Slope, the effects of site, year, browsing, and the 2-way interactions of browsing with year and with site were significant $(\mathrm{P}<0.05)$ for number of flowers per branch, number of seeds per branch, and the number of seeds per flower. The effects of site, year, and the 2way interactions of browsing with site and year were significant $(P<0.05)$ for the number of flowers per total twig length and the number of seeds per total twig length. Therefore reproductive responses were analyzed separately for each site. On years and at sites with highest seed production, branches on unbrowsed shrubs produced many more flowers and seeds than those on browsed shrubs (Table 1). The number of flowers per branch was significantly greater for unbrowsed than browsed shrubs for all years at Poison Mountain and Telephone Hollow, for 1997 and 1998 at Widdop Mountain, and for 1999 at Gregory Basin. Flowers per total twig length were also greater for all

\section{Discussion}

Utilization, annual growth, and reproductive responses of true mountain mahogany varied among sites within a given year and among years for a given site. Over the 4 years of the study, annual growth of browsed shrubs compensated for twig length lost to herbivory, even when utilization was over $300 \%$. Over $100 \%$ of annual growth was browsed during the winters of $1996 / 1997$ or $1997 / 1998$ for 2 of the 4 sites at the North Slope and for the Gardner Canyon site. Animals browsed second and third year growth, as well as annual growth on these sites. Twig growth at the North Slope was greatest in 1997 and 1998, and at Gardner Canyon in 1998. After peaking in the winter of $1997 / 1998$, utilization dropped to less than $65 \%$ for all sites in the winter of 1998/1999. Greater growth in 1997 and 1998 may have resulted in less utilization in the winter of 1998/1999, even though animal use was high (Turley et al. 2003).

There was no clear relationship between amount of utilization and annual regrowth among browsed shrubs at different sites. For example, utilization at Poison Mountain was 46,41 , and $50 \%$, while that at Telephone Hollow was 302, 306, and $61 \%$ for the winters of $1996 / 1997$, $1997 / 1998$, and 1998/1999. Greater annual growth in 1997 and 1998 compensated for lost twig length in both cases, allowing total twig length on browsed shrubs to be maintained or slightly increase over time (Figs. 3 and 5). Annual growth compensated, but did not over-compensate for tissue lost to herbivory. Therefore, dimensions of browsed shrubs stayed the same, and did not increase in size over the study period. However, unbrowsed shrubs at 4 sites were larger than browsed shrubs (Turley et al. 2003). Although twigs on browsed shrubs grew proportionally more than those on unbrowsed shrubs, twig length per branch was greater and increased more over time on unbrowsed than browsed shrubs at the North Slope (Fig. 5). Even though annual growth compensated for length lost to herbivory after heavy utilization, it was not sufficient to allow browsed shrubs to increase in total twig length and equal the size potential of unbrowsed shrubs.

Grazing-tolerant shrubs like true mountain mahogany are able to compensate for tissue lost to herbivory because they have available growing points and allocate resources to them (Wandera et al. 1992). Under natural herbivory and climatic conditions, there appears to be a dynamic 

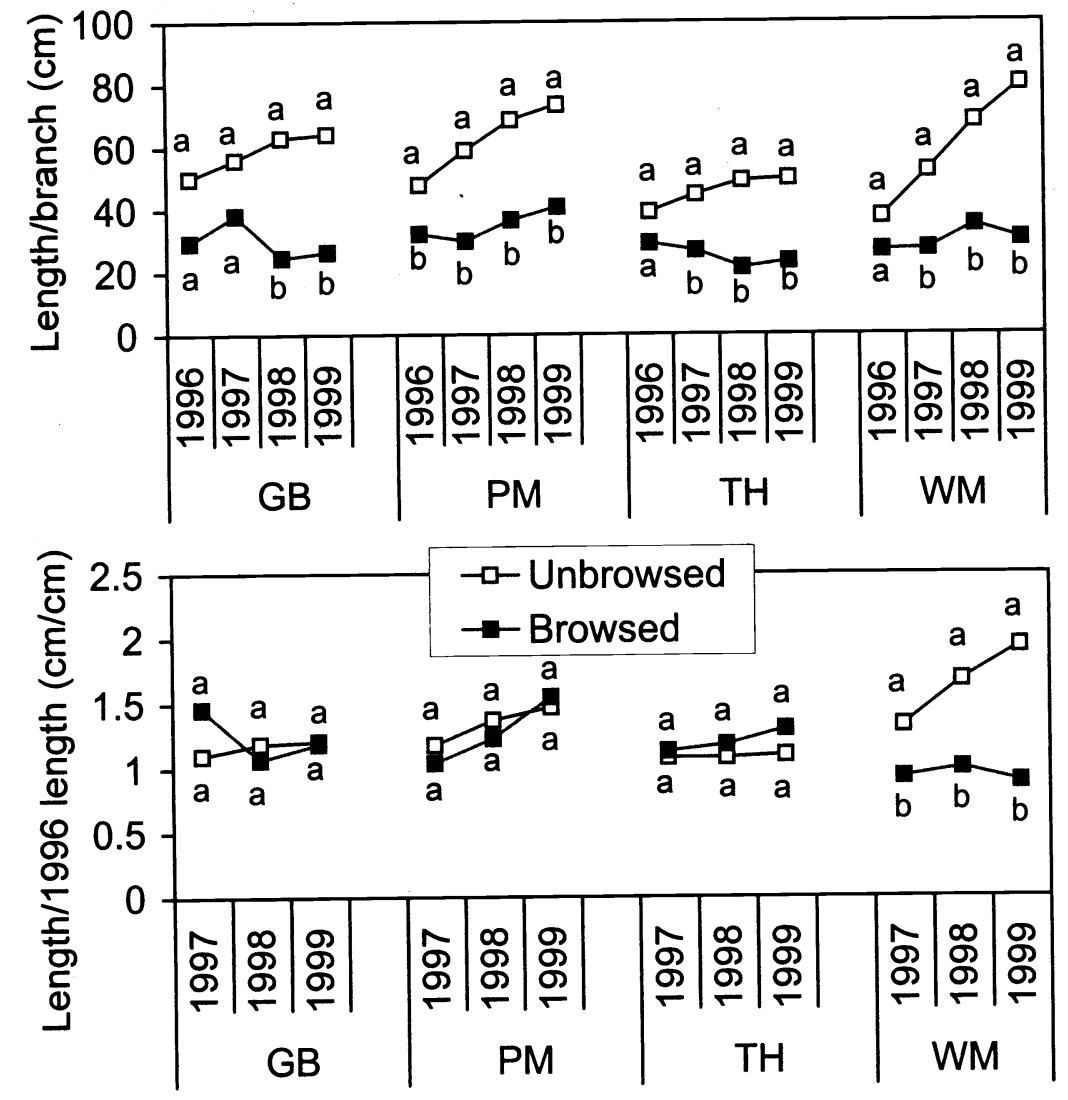

Fig. 5. Total twig length per branch (above) and per total twig length in 1996 (below) for unbrowsed and browsed true mountain mahogany shrubs at 4 sites on the North Slope of the Uinta Mountains, Utah. GB = Gregory Basin, PM = Poison Mountain, TH = Telephone Hollow, WM = Widdop Mountain. Different letters within a site and year indicate a significant difference $(\mathrm{P}<0.05)$.

interaction among animal use, utilization, compensatory annual growth, and resource availability for these shrubs. If resource availability is high during the summer growing season, compensatory growth to replace twig length lost to herbivory during the previous winter will also be high, and total twig length should increase. If animal use or stocking the following winter stays the same as the previous winter, utilization should decrease due to increased biomass from the high compensatory growth. If resource availability is low during the summer growing season, compensatory growth will also be lower, total twig length less, and utilization the following winter would increase under the same animal use. The exact relationship among these variables is not necessarily known for a site. As resource availability and compensatory growth increase for a set of years, total twig length and shrub size could increase from negative to zero or positive where utilization is high $(>100$ $\%)$, and to that dictated by long-term resource availability or site potential species, and that long-term effects of heavy utilization may have a negative effect, when short term heavy utilization has a stimulatory effect on growth. Longterm heavy utilization ( $>100 \%$ annual growth) may reduce carbon fixation and water and nutrient uptake by reducing photosynthetic tissue above ground and root mass below ground. The long-term result may be reduced shrub size and therefore productive potential of the stand, even if shrub density does not decrease (Roundy and Ruyle 1989).

As has been recommended by Holechek et al. (2001) from an extensive review of years of stocking rate research across many vegetation types, moderate stocking and utilization is best when grazing pressure is relatively constant from year to year. The dynamics of big game animal use, resource availability, annual growth, and utilization make it very difficult to manage true mountain mahogany stands for optimum production. Although heavy use ( $>100 \%$ of annual growth) in 1 or 2 years may not be injurious in the long term, it is best to manage for moderate use on most years and avoid the damage that could occur if utilization is high and resource availability is low.

Browsing had much more of a negative effect on plant reproductive responses than on vegetative responses in this study (Table 1). Unbrowsed shrubs produced many more flowers and seeds than browsed shrubs. Seed and flower numbers on unbrowsed and browsed shrubs were highest in 1998 when either winter-spring or June precipitation was highest. For browsed shrubs, seed and flower numbers varied more among years than among sites with different utilization percentages within a year. Even though utilization was over $300 \%$ at Telephone Hollow in the winters of 1996 to 1997 and 1997 to 1998 , flower and seed production were much higher in 1997 and 1998 than in 1999 when utilization the previous winter was only $62 \%$.

Because flower production occurs before annual growth, new growth does not provide any reproductive potential for that year in true mountain mahogany shrubs (Walker and Turley 1999). Lack of second year and older wood due to browsing may be partially responsible for significantly less seed production on browsed than unbrowsed plants. However, the fact that unbrowsed shrubs also had greater numbers of flowers and seeds per total twig length suggests that less wood availability may not fully account for lower reproductive responses of browsed than unbrowsed shrubs. Roundy and Ruyle 

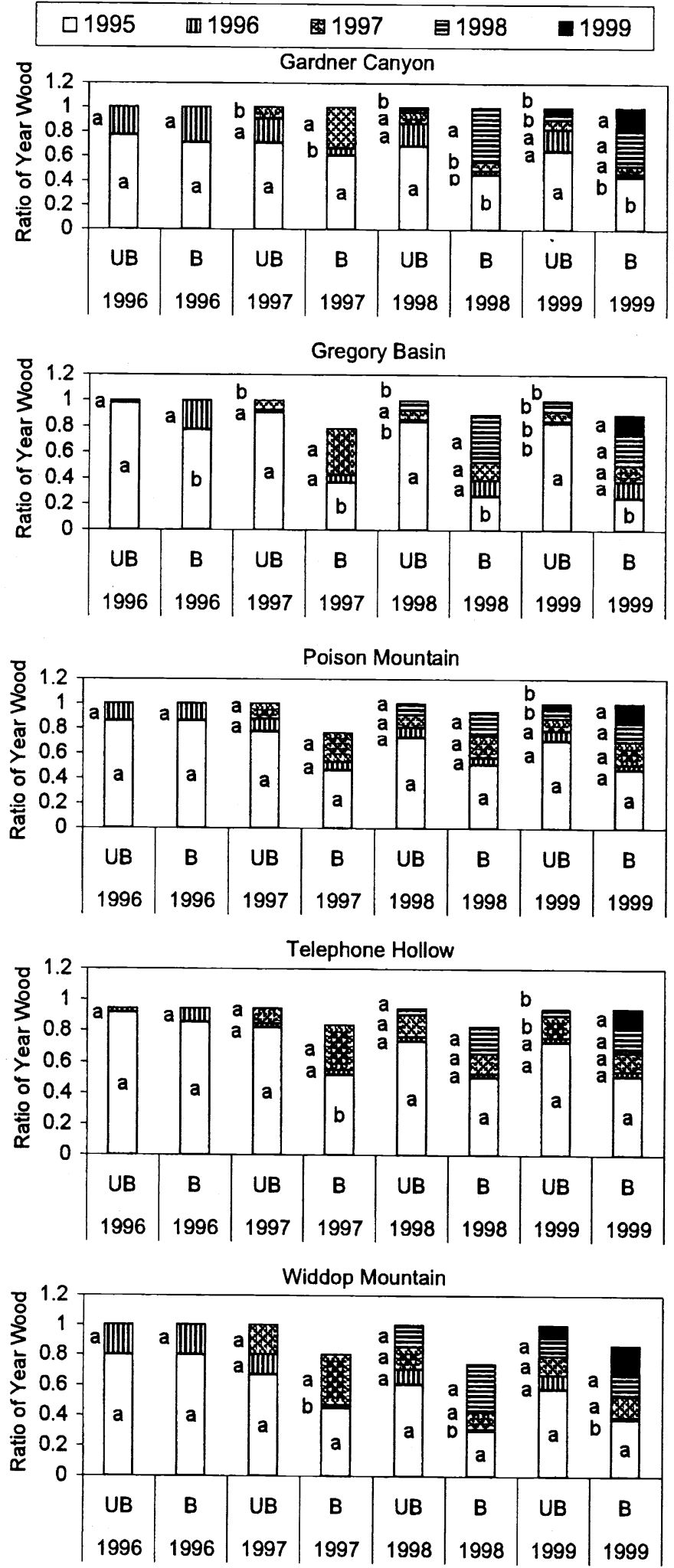

Fig. 6. Ratio of wood length grown during different years (bar patterns) to total length for a given year ( $x$ axis) for unbrowsed and browsed true mountain mahogany shrubs at 5 sites in Utah. UB = unbrowsed, $B=$ browsed. Different letters within a site and year indicate a significant difference between unbrowsed and browsed for that year wood as indicated by the same bar pattern $(P<0.05)$.
(1989) also found much fewer flowers and seeds on browsed than unbrowsed jojoba (Simmondsia chinensis (Link) Schn.), a grazing tolerant shrub in the Sonoran Desert. Effects of lower flower and seed production due to browsing on long-term seedling establishment and stand renewal for long-lived shrubs are difficult to predict. Turley (2000) found similar densities of seedlings and other size classes of true mountain mahogany inside and outside exclosures at these sites. It is expected that browsed stands will still have sufficient reproduction to maintain the populations of these shrubs over the long term, as long as shrub size is maintained.

\section{Literature Cited}

Briske, D.D. 1993. Grazing optimization: a plea for a balanced perspective. Ecol. Appl. 3:24-26.

Briske, D.D. and R.K. Heitschmidt. 1991. An ecological perspective. p. 11-26 In: R.K. Heitschmidt and J.W. Stuth (eds.) Grazing management. An ecological perspective. Timber Press. Portland, Ore.

Davis, J.N. 1990. General ecology, wildlife use, and management of the mountain mahoganies in the Intermountain West. p.1-14 In: K.L. Johnson (ed.) Proc.Fifth Utah Shrub Ecology Workshop: The genus Cercocarpus. Utah State University. Logan, Utah.

Holechek, J. L., R. D. Pieper, and C. H. Herbel. 2001. Range management principles and practices. Fourth edition. Prentice Hall, Upper Saddle River, N.J.

Littell, R.C., G.A. Milliken, W.W. Stroup, and R.D. Wolfinger. 1996. SAS system for mixed models. SAS Institute Inc. Cary, N.C.

NOAA. 1995-1999. Climatological data. Annual report for Utah. National Climatic Data Center, Ashville, N.C.

Noy-Meir, I. 1993. Compensating growth of grazed plants and its relevance to the use of rangelands. Ecol. Appl. 3:32-34.

Painter, E.L., J.K. Detling, and D.A. Steingraeber. 1989. Grazing history, defoliation, and frequency-dependent competition: effects on two North American grasses. Amer. J. Bot. 76:1368-1379.

Patten, D. 1993. Herbivore optimization and overcompensation: does native herbivory on western rangelands support these theories? J. Appl. Ecol. 3:35-36.

Roundy, B.A. and G.B. Ruyle. 1989. Effects of herbivory on twig dynamics of a Sonoran desert shrub Simmondsia chinensis (Link) Schn. J. Appl. Ecol. 26:701-710.

Shepherd, H.L. 1971. Effects of clipping on key browse species in southwestern Colorado. Game Research Section, Colorado Division of Game, Fish and Parks Game Range Investigations, Federal Aid Project W10-R. Technical Publication Number 28. State of Colorado. 
Trlica, M.J. and L.R. Rittenhouse. 1993. Grazing and plant performance. Ecol. Appl. 3:21-23.

Turley, D. 2000. Effects of browsing on true mountain mahogany (Cercocarpus montanus Raf.). MS Thesis, Brigham Young Univ., Provo, Utah.

Turley, D., B.A. Roundy, and S.C. Walker. 2003. Community and shrub size responses of true mountain mahogany to browsing. $\mathrm{J}$ Range Manage. 56:600-607.
USDA Forest Service. 1979. Allotment analysis handbook. Southwestern Region 3. Albuquerque, N. M.

Walker, S.C. and D. Turley. 1999. Characteristics of mountain mahogany (Cercocarpus) species and hybrids in Utah hybrid zone. p.32-34 In: E.D. McArthur, W.K. Ostler and C. L. Wambolt (compilers), Proc. shrubland ecotones. USDA Forest Service Rocky Mountain Research Station. RMRS-P-11 Ogden, Utah.
Wandera, J. L., J. H. Richards, and R. J. Mueller. 1992. The relationships between relative growth rate, meristematic potential, and compensatory growth of semiarid-land shrubs. Oecologia 90:391-398.

Williamson, S.C., J.K. Detling, J.L. Dodd, and M.I. Dyer. 1989. Experimental evaluation of the grazing optimization hypothesis. J. Range Manage. 42:149-152. 